\title{
The evolution of the spatial structure of the Irish dairy processing industry
}

\author{
Proinnsias Breathnach \\ Department of Geography, National University of Ireland, Maynooth
}

\begin{abstract}
The Irish dairy processing industry has undergone a profound process of spatial reorganisation since the original introduction of the creamery system in the late nineteenth century. This process is described in the form of six distinct but interwoven episodes: the elimination of the privately-owned creameries, the amalgamation of dairy co-operatives into larger units, internal rationalisation of processing within these units (including the closure of branch creameries), concentration of on-farm milk production and, most recently, internationalisation accompanied by the movement towards privatisation of the largest dairy processing co-operatives. Among the outcomes of these combined processes have been the widespread elimination of dairy farmers from the industry and the reduction of those remaining to the essential status of contract suppliers to large agribusiness enterprises whose primary orientation is now increasingly focused on private shareholders and overseas operations.
\end{abstract}

Key index words: creameries, co-operatives, amalgamation, rationalisation, internationalisation, privatisation.

\section{Introduction}

Traditionally, agricultural geography has been mainly concerned with the nature of farming systems and their spatial structure. However, Bowler and Ilbery (1987) have called for a refocusing away from this narrow preoccupation with on-farm production towards the role of agriculture in the overall food supply system and the consequent links between agriculture and the broader urban-industrial system. Agriculture, therefore, comprises just one component of an integrated commodity chain which also includes, on the upstream side, material and service inputs to farming (feedstuffs, pharmaceuticals, advisory services, etc.) and, on the downstream side, processing and marketing of agricultural products. Distinctive features of this so-called 'agro-food system' are its increasingly global scope and its growing domination by large agribusiness firms (Whatmore, 1995).

Such an approach seems particularly appropriate to the Irish dairy industry, which has witnessed growing integration into national and international markets since systematic commercial production of dairy products was first introduced in the late-seventeeth century. This process was accelerated when off-farm milk processing became widely established with the advent of the creamery system in the late-nineteenth century. Then, in the second half of the twentieth century, the Irish dairy industry - in common with the experience of agriculture throughout developed market economies - underwent a further process of revolutionary change arising from "the progressive extension of technological, organisational and economic rationality into the arena of farm operations, linking them even more closely to the other sectors of the economy, both materially and in ethos" (Wallace, 1984, quoted in Healey and Ilbery, 1985b: 2). The specific outcomes of this general process have been summarised by 
Bowler (1992) under the following three headings: intensification (that is, increased output per unit of land), concentration (of land among fewer operators), and specialisation (both by individual farms and by region).

Associated with these on-farm changes has been a profound process of reorganisation of the spatial structure of the Irish dairy processing industry. The remainder of this paper documents the progress of this reorganisation process through the course of the twentieth century. The paper begins by outlining the initial spatial structure established by the introduction of the creamery system in the late-nineteenth century, and then traces the interwoven processes which combined to produce sweeping changes in this structure as the succeeding century progressed. These include the elimination of the privately-owned creameries from the sector, the amalgamation of dairy co-operatives into larger units, internal rationalisation of processing within these units (including the closure of branch creameries), concentration of on-farm milk production and, finally and most recently, internationalisation accompanied by the movement towards privatisation of the largest dairy processing cooperatives.

\section{The emergence of the creamery system in the late-nineteenth century}

In the early-nineteenth century, Ireland was probably the world's leading exporter of dairy produce (especially butter). The dairy industry was mainly developed in the southern province of Munster, and in particular in a region encompassing all of Limerick, north Kerry, North and north-west Cork and west Tipperary (identified as the 'Mid-Munster Intensive Dairying Region' in Figure 1). Dairying was also a major component of the agricultural economy in the adjoining 'Southern Dairying with other Enterprises Region' and in the 'Drumlin Belt Dairying and Cattle Region' of south-west Ulster and adjoining parts of Leinster and Connacht. Dairy processing consisted almost entirely of the production of butter, which was carried out on individual farms prior to sale to local merchants who, in turn, sold the butter on to merchants based in the main ports (especially Cork and Waterford). Here, the butter from different sources was blended in butter 'factories' prior to export (mainly to Britain) (Daly, 1991).

The Irish dairy industry was revolutionised in the late-nineteenth century by the introduction of the centrifugal separator, first developed in Germany in the early 1870s. This device allowed much faster and more thorough separation of cream from milk, but required the milk of a number of dairy farms for economical operation. This meant that milk processing had to move from the individual farm to centralised plants which became known as creameries. The first creamery incorporating the new technology to be established in Ireland was opened in county Limerick in 1884.

The creamery system subsequently spread rapidly, initially in the form of privatelyowned or 'proprietary' creameries. However, after 1889 (when the first co-operative was established, also in county Limerick), co-operative creameries also became increasingly common. Frequently, the latter were established in direct competition with the former (and sometimes with each other), leading eventually to a situation where the total number of creameries became uneconomic in relation to the available milk supply. By 1906, almost 800 creameries were in operation throughout Ireland. However, whereas, nationally, just over one half of all creameries were proprietary in ownership, in fact this form predominated in Munster whereas co-operatives predominated in the other three provinces, especially in Ulster (Table 1). 


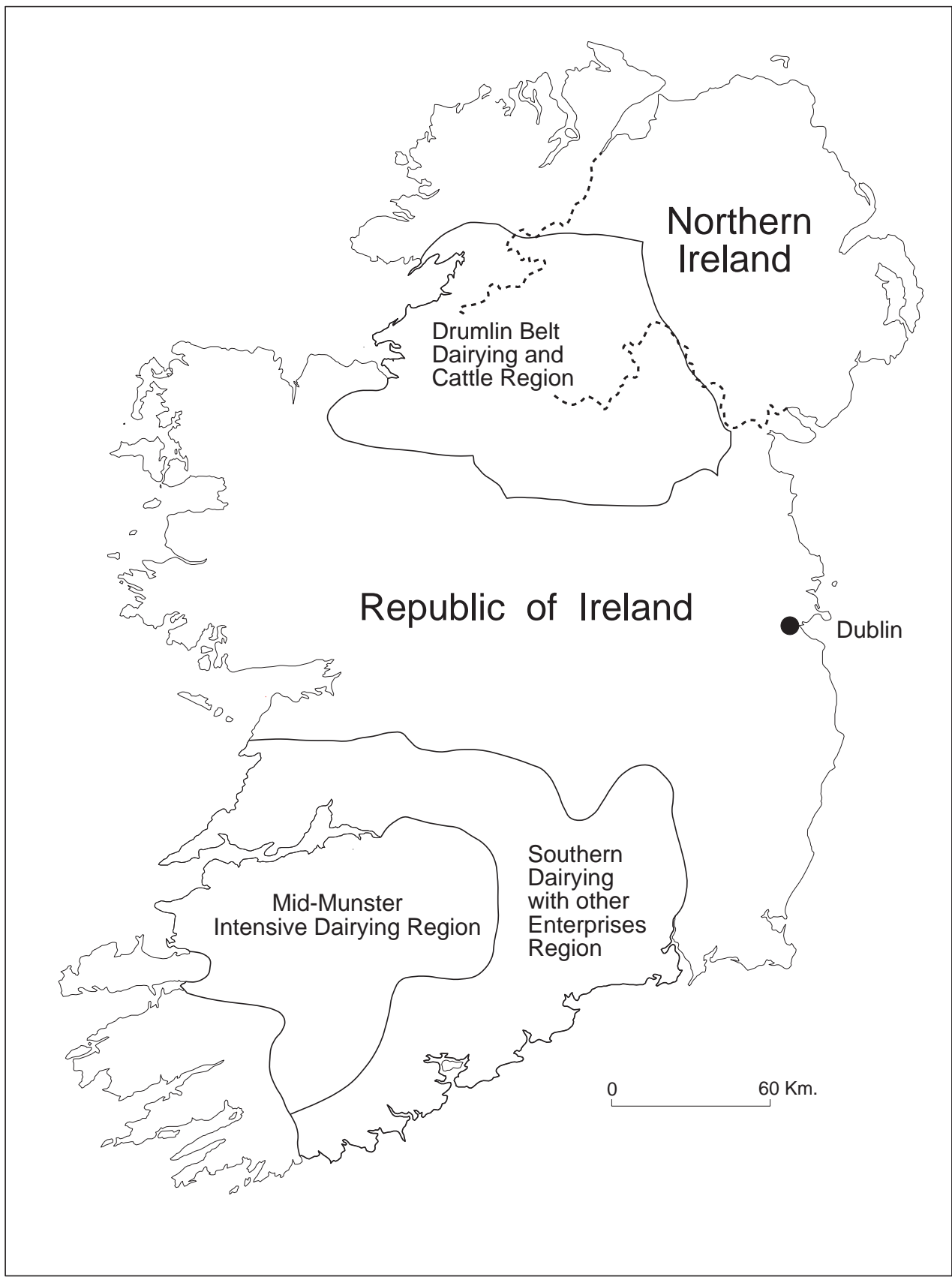

Figure 1: Ireland: dairying regions (after Haughton and Gillmor, 1979, Figure 9).

Given the transport conditions of the time, and the fact that a large number of suppliers was not required to support a separator, many central butter-making creameries were linked with outlying 'auxiliary' or branch creameries whose function was to separate cream from the milk of suppliers in the immediate hinterland. This cream was then transported to the central creamery for processing into butter, thereby saving substantially in transport costs. A very 
simple spatial hierarchy therefore emerged: each branch creamery served a surrounding radius of around five kilometres, embracing perhaps 50-100 farmers. These brought their milk daily to the creamery in cans for separation; the skim milk left over from the separation process was returned to the farmer for feeding to calves and pigs, and the cream was transported onwards to the central creamery for processing into butter, some of which was sold locally but most of which was destined for major urban markets, primarily in Great Britain. The number of branch creameries associated with a central creamery varied considerably, depending on local geographical and historical circumstances: in many cases a butter-producing creamery had no branches at all.

Table 1: Distribution of creameries by province, 1906.

\begin{tabular}{lccccc}
\hline Province & Proprietary & $\%$ & Co-operative & $\%$ & Total \\
\hline Munster & 365 & 76.5 & 112 & 23.5 & 477 \\
Ulster & 28 & 14.7 & 162 & 85.3 & 190 \\
Connacht & 16 & 26.2 & 45 & 73.8 & 61 \\
Leinster & 20 & 35.7 & 36 & 64.3 & 56 \\
Ireland & 429 & 54.7 & 355 & 45.3 & 784 \\
\hline
\end{tabular}

Source: Daly (1991), Table 3.5.

The creamery system, with its requirement of daily milk deliveries by farmers, created an entirely new social interaction pattern in much of rural Ireland, as farmers were afforded a regular opportunity to come together and discuss current affairs (frequently in public houses located adjacent to the creameries). While much of this consisted of nothing more than gossip and idle chat, these daily meetings also became an important mechanism for the diffusion of information regarding market conditions, prices and technology. The centrality of the local creamery in the social life of dairying regions has been encapsulated by Frawley (1993: 25) in the following passage-

"...the creamery is the focal point of a system of intimate and familiar networks of social relationships which have a place of their own in the community and in the everyday lives of many suppliers...In many ways going to the creamery and what it entails takes on a meaning and life of its own, almost independent of the functional purpose it serves".

\section{The elimination of the private creamery sector}

While the number of co-operative creameries continued to expand in the first two decades of the twentieth century (from 254 in 1905 to 336 in 1920), there was a sharp reduction in the number of private operations (from 537 to 180) in the same period. This reflects the early over-proliferation of total creamery numbers, and the lower tolerance of the private sector to the low-profit or loss-making situations which resulted. The slump in agricultural prices after World War I created very difficult circumstances for the creamery sector, a position which was further aggravated by on-going 'milk wars' between rival private and co-operative operations which were competing for milk supplies in many areas (Bolger, 1983). The newly-independent Dublin Government stepped in via the establishment in 1927 of the Dairy Disposal Company (DDC) with a remit, in effect, to take over both the private 
creamery sector and any insolvent co-operatives and to either close them down altogether or transfer them to surviving co-operatives. Meanwhile, the establishment of new creameries was to be controlled by a licensing system introduced under the 1928 Creameries Act.

Within three years, the DDC had acquired 170 private creameries ( 80 percent of the total), about half of which were closed down, with a further quarter being transferred to cooperative ownership. The remainder were operated directly by the DDC itself, these being mainly viable operations located in areas where suitable co-operatives to which they might be transferred were not available and where it proved unfeasible to set up new co-operatives to run the creameries concerned (Bolger, 1977). The key element in the takeover of the private dairy processing sector was the purchase by the DDC of the Limerick-based Condensed Milk Company, which alone operated over 100 creameries throughout Munster, as well as a number of milk condensation plants (Foley, 1993). Some insolvent co-operatives were also acquired, as were all remaining private operations in the 1930s and 1940s.

While the original idea was that (in accordance with its name) the DDC would dispose of all the viable creameries which came into its possession, by the 1940s the company appeared to have lost its initial reforming mission, and became instead a permanent feature of the dairy processing industry. While becoming increasingly resistant to takeover of its creameries by co-operatives, the DDC assumed a developmental role, establishing new creameries, many of them in previously undeveloped dairying areas in the midlands and the west. This was done partly to expand milk supplies for its existing creameries and partly as an element of Government social policy (Bolger, 1977). Ultimately, the DDC ended up operating seventeen central creameries and a large number of branches, mainly in Kerry and Clare, but with a significant presence also in Tipperary, Limerick and Cork. By the early 1960s, the company accounted for one quarter of the total milk throughput of the Irish creamery sector.

Overall, the DDC had a profound impact on the Irish dairy industry. Apart from the virtually complete elimination of the private creamery sector, the company had overseen a reduction in the number of co-operative creameries from 336 to 215 between 1920 and 1940. While there was an obvious need to tackle the overproliferation of creameries which had occurred in the early part of the century, the decision to do so via the summary elimination of the privately-owned component of the industry is worthy of note- especially given the conservative economic outlook of the governing party, Cumann na nGaedheal (Lee, 1989). The fact that this party had a strong social base among the commercial farming sector (Kennedy et al., 1988) was presumably a key factor influencing this decision.

\section{Postwar creamery amalgamation}

While the early proliferation of small creameries can be attributed to the short distances which milk could be transported given the prevailing transport methods of the late-nineteenth century, both the advent of motorised transport and the reorganisation carried out by the DDC permitted a process of differentiation and stratification to take place in the creamery sector as the twentieth century progressed, with better-placed and better-managed creameries expanding processing levels and moving ahead of the others. Thus, in 1951, of the almost 200 dairy co-operatives still in operation in the Republic of Ireland at the time, just five accounted for 20 percent of the total turnover of the entire sector.

By this stage, a couple of pointers for the future development of the industry had been 
put in place. In 1948 a number of co-operatives in south Limerick established the Golden Vale Federation which operated a cheese factory in Charleville on the Cork/Limerick border. This was an early example of diversification from butter production, facilitated by the onset of motorised transport. Similarly, in 1951, some 38 co-operative creameries from Kilkenny and Tipperary established a chocolate crumb factory at Carrick-on-Suir in conjunction with English private interests. However, it took quite some time for these examples of cooperation between co-operatives to take on a more permanent structure.

After a decade of relative stagnation in the 1950s, the Irish dairy industry entered a phase of rapid expansion in the 1960s, due partly to general economic buoyancy in both the domestic and international economies, and partly to the introduction of direct Government supports. The Government had decided to move away from the policy of protectionism which had been in place since the early 1930s; consequently there was need for the restructuring of indigenous industry in order to prepare it for growing conditions of free trade. A number of sectoral studies were carried out in pursuit of this objective, and that for the dairy industry, carried out in 1963, recommended the amalgamation of dairy co-operatives into larger groups in order to achieve economies of scale and specialisation. Larger processing plants were also required in order to absorb the growing output of milk resulting from new Government supports: national milk output rose from 480M gallons $(21.8 \mathrm{MHl})$ in 1960 to $740 \mathrm{M}$ gallons (33.6MHl) in 1973. In particular, it was important to diversify processing away from butter, which was the sole product of the great majority of creameries, to alternative products such as cheese and milk powder.

Following on from this report, the Minister for Agriculture commissioned an American expert on agricultural co-operatives, Joseph Knapp, to conduct an appraisal of the Irish agricultural co-operative sector. His report (Knapp, 1964) reiterated the need for amalgamation and rationalisation and recommended that the Irish Agricultural Organisation Society (IAOS), the umbrella body for the dairy co-operative movement, should be given responsibility for working out general reorganisation plans for the dairy industry. This latter recommendation was incorporated into the Second Programme for Economic Expansion, launched in 1964. Further support for rationalisation was provided by a set of econometric studies carried out by O'Dwyer (1968a; 1968b) which showed how substantial cost savings could be made by centralising milk processing in larger plants, notwithstanding the additional transport costs involved in transferring milk supplies over longer distances. O'Dwyer concluded that the optimum number of plants for processing the existing milk supply in the Munster counties and Kilkenny in 1965 was just 23, compared with the actual number of 143 which were in operation in the area at the time.

Taking on board the remit recommended by Knapp, the IAOS in 1966 published detailed proposals for the reorganisation of the dairy industry (IAOS, 1966). These provided for the amalgamation of the 192 central creamery operations (including those operated by the DDC), with an average milk throughput of less than two million gallons $(91,000 \mathrm{Hl})$ each, into just nineteen units, with an average milk throughput of 19 million gallons $(0.86 \mathrm{MHl})$ each. The general strategy involved in this plan was to bring adjacent co-operatives together, frequently with a larger co-operative acting as a focus to which its smaller neighbours would be attracted. As O'Leary (1983: 132) put it: “The original concept of rationalisation of the milk supply...was to concentrate the available milk supplies from producers in processing plants within defined geographical areas, thus establishing the situation wherein the milk supply would gravitate to the processing plant nearest to the primary producer". Apart from 
facilitating the minimisation of transport costs, this approach offered (at least in theory) the prospect of forging a sense of common identity, based on territorial contiguity, among the enlarged units.

\section{The pattern of co-operative amalgamation}

By this stage, the first major amalgamation had already taken place, when in 1964 four of the five co-operative societies in county Waterford merged to create Waterford Cooperative Society. This pioneering move in the case of the Waterford societies was undoubtedly facilitated by the small number of co-operatives in the county and the fact that there was little overlap in their territories. This contrasts with the cases of counties Limerick and Tipperary, which respectively possessed 40 and 24 separate co-operatives in 1960, with a high level of territorial interpenetration and a history of mutual suspicion between them (Breathnach, 1992).

The process of amalgamation set off in Waterford subsequently spread rapidly throughout the industry. The 192 creamery units identified in the IAOS's 1966 proposals were reduced to just 46 by 1978 and 35 by 1990. The DDC was finally disbanded in the early 1970s and its creameries transferred to co-operative ownership. However, despite the attempts by the IAOS to implement an overall master plan, the actual process of amalgamation which materialised in this period was far from efficient from either an economic or geographical point of view. For a start, there was widespread hostility to the idea of amalgamation among smaller co-operatives. This was partly attributable to local pride, and in particular to resistance to the idea of being 'taken over' (as amalgamation was frequently perceived) by larger neighbouring co-operatives which were often seen as traditional rivals. The desire of co-operative managers to retain control of their own 'fiefdoms' (Murtagh, 1986) and the fear that amalgamation would involve local job losses contributed further to the negative attitude to rationalisation which was common among smaller co-operatives. Some co-operatives managed to postpone, or even avoid altogether, the amalgamation process by concluding supply contracts with a number of foreign-owned (mainly British) food firms which entered the Irish milk-processing industry in the 1960s and 1970s (Foley, 1993).

An additional factor which had a considerable bearing on the amalgamation process was that, in the early to mid-1960s, a number of the larger co-operatives had made considerable investments in processing plant, and did not have sufficient internal supplies to make optimum use of this plant. They therefore were anxious to find additional external supplies, and amalgamation was seen as the best means of guaranteeing supplies from external sources. Many of these co-operatives had developed long-standing arrangements for the purchase of surplus milk from other, smaller (and sometimes far-removed) co-operatives, long before amalgamation was put on the agenda. These arrangements then paved the way for subsequent amalgamations, but frequently not in compliance with the amalgamation proposals put forward by the IAOS.

A further obstacle to the achievement of a rational amalgamation process was the fact that the IAOS itself had neither the statutory nor the moral authority among its own members to secure the implementation of its amalgamation proposals. It might be noted that, despite the strong case which had been made to it for a radical reorganisation of what was, at the time, the country's second largest industry, the Government nevertheless opted out of any direct involvement in the reorganisation process. 
The inevitable outcome of all these considerations was that the amalgamation process proved to be slow and gradual, piecemeal and incomplete, and frequently unharmonious. While widespread amalgamation did occur, the overall outcome was not a very rational structure. As O'Leary (1983: 134) put it, following the main phase of amalgamations in the 1970 s, "...the final map showing the location of primary suppliers relative to their processing plant is a crazy geographical patchwork".

\section{The amalgamation process in the Mid-Munster region ${ }^{1}$}

To illustrate the manner in which the amalgamation process actually worked out at local level, this section of the paper presents a case study of the process in the Mid-Munster region, the heartland of the dairy industry, embracing county Limerick, North Cork and West Tipperary. In 1964, this region accounted for one third of Ireland's total creamery milk output, and possessed 168 creamery installations, including 73 central and 95 branch creameries (Figure 2). Most of these were in co-operative ownership, although there was also a significant DDC presence.

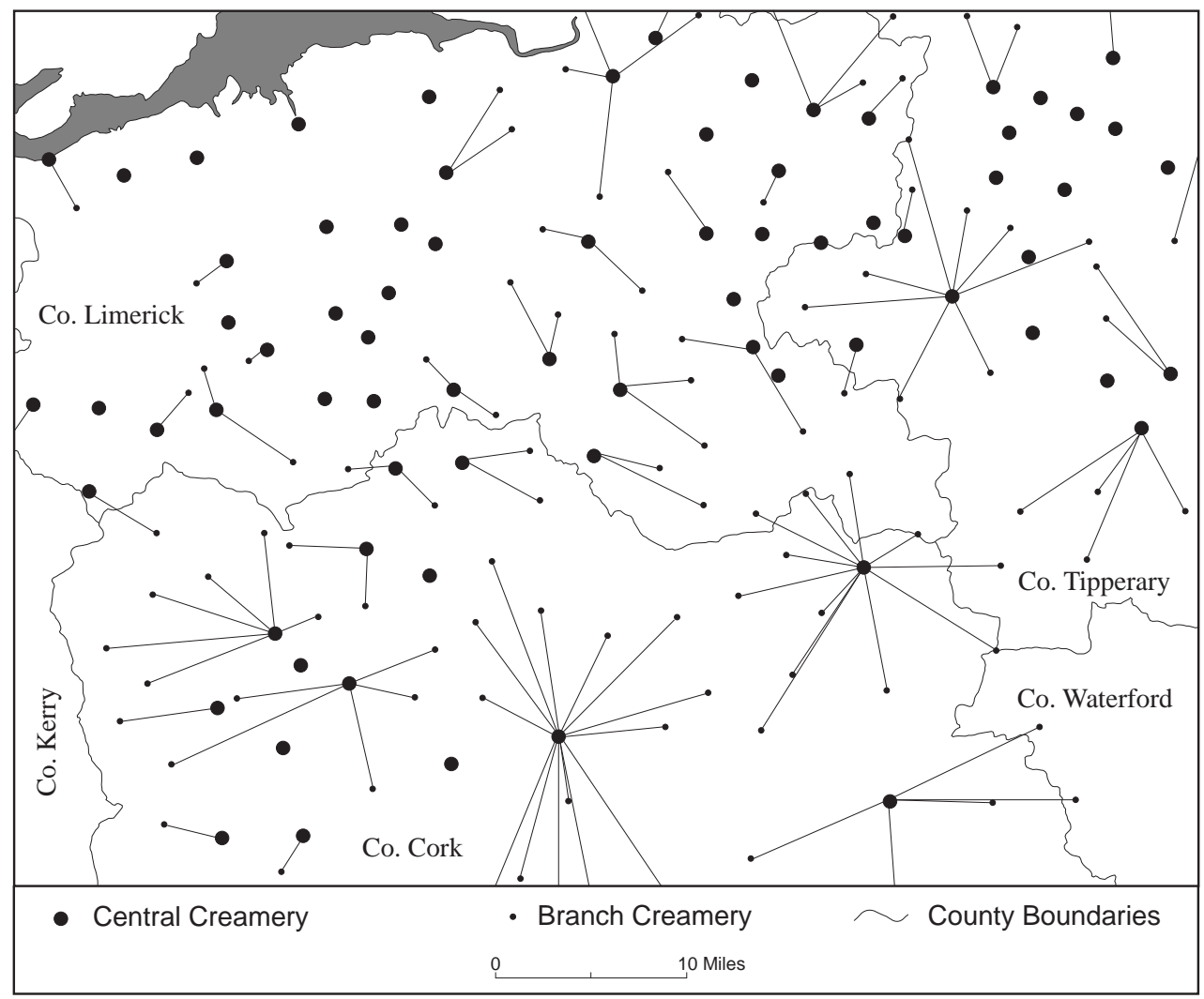

Figure 2: Creameries in the Mid-Munster dairying region, 1964.

A peculiar feature of the creamery structure in county Limerick in the early 1960s was its lack of consolidation, with 20 of its 41 central creameries functioning as stand-alone operations, and the remaining 21 having an average of 1.5 branches each (the largest having 
just four branches). By contrast, only four of the fifteen creameries in north Cork were standalone operations, while three of the remainder had a total of 24 branches between them. The picture in Tipperary is distorted by the presence of a number of DDC creameries, but here also, Tipperary Co-operative had acted as the focus of a significant degree of consolidation. While a number of co-operatives in south Limerick were part of the Golden Vale Federation, this was a very loose arrangement with a fluctuating membership. Overall, the small scale of the co-operative sector in Limerick rendered it vulnerable to piecemeal colonisation, in particular by the larger operations based south of the border in north Cork.

The IAOS 1966 proposals envisaged dividing most of the creameries in the Mid-Munster area into six groups (see Figure 3, in which the Roman numerals refer to the group numbering system used by the IAOS; branch creameries are not shown). In accordance with the general approach adopted by the IAOS, four of these were based on amalgamating smaller units with neighbouring large co-operatives: Mitchelstown (XI); Ballyclough (XII); Tipperary (XVIII); and Nenagh (XIX). Group XIV involved the creation of a consolidated co-operative from most of the members of the Golden Vale Federation, focused on the Charleville cheese plant.

The sixth proposed group (XVI in north and west Limerick) was to be built on very flimsy foundations. The twelve co-operatives making up this group had a combined milk throughput in 1964 of just $12.9 \mathrm{M}$ gallons $(586,000 \mathrm{Hl})$, compared with an average of $26.7 \mathrm{M}$ gallons $(1.2 \mathrm{MHl})$ for the other five proposed IAOS groups in the region. It therefore had a very limited supply base upon which to develop a diversification strategy. Further, unlike the other groups, only butter was produced within the group, so that there was no diversified plant which could provide the focus for amalgamation. In addition, there was no dominant entity in the group around which amalgamation could be based: the largest co-operative in the group had a milk throughput of only $1.9 \mathrm{M}$ gallons $(86,000 \mathrm{Hl})$, compared, for example, to $15.4 \mathrm{M}$ $(0.7 \mathrm{MHl})$ in the case of Mitchelstown, $10 \mathrm{M}(450,000 \mathrm{Hl})$ in the case of Ballyclough, and $5.5 \mathrm{M}$ $(250,000 \mathrm{Hl})$ in the case of Tipperary.

The peculiar wedge-like geographical shape of the proposed Group XIV reflected the distribution of members of the Golden Vale Federation at the time the IAOS proposals were drawn up. The proposals accepted existing creamery affililiations as given, although this did not always comply with the territorial compactness which economic rationality would have suggested. This was also seen in the fact that, the year before the IAOS produced its proposals, Mitchelstown Co-operative had taken over two smaller co-operatives in east Limerick, thereby driving a wedge between the proposed Groups XIV and XVIII (Figure 3).

It is hardly surprising from what has been written above that the actual pattern of amalgamations which eventually emerged in Mid-Munster in the 1960s and 1970s departed significantly from what was originally proposed by the IAOS (Figure 3 ). There is not space here to go through the chronology of individual amalgamations, but it would be fair to describe it as an analytical feast for the game theorist, consisting to a large extent of a sequence of pre-emptive strikes and subsequent reactionary moves. The overall result was a high degree of intermixing of the territories of the larger co-operatives and the continued independent survival of some smaller units - a veritable nightmare for those advocating spatial rationality.

Beginning with Group XIV, most of the units in this grouping did proceed to form the Golden Vale Co-operative, as envisaged by the IAOS. However, this co-operative also came to embrace units which the IAOS had allocated to Groups XVI (7), XVIII (1) and XIX (2), plus a unit on the Limerick/Kerry border which the IAOS had allocated to a proposed new 


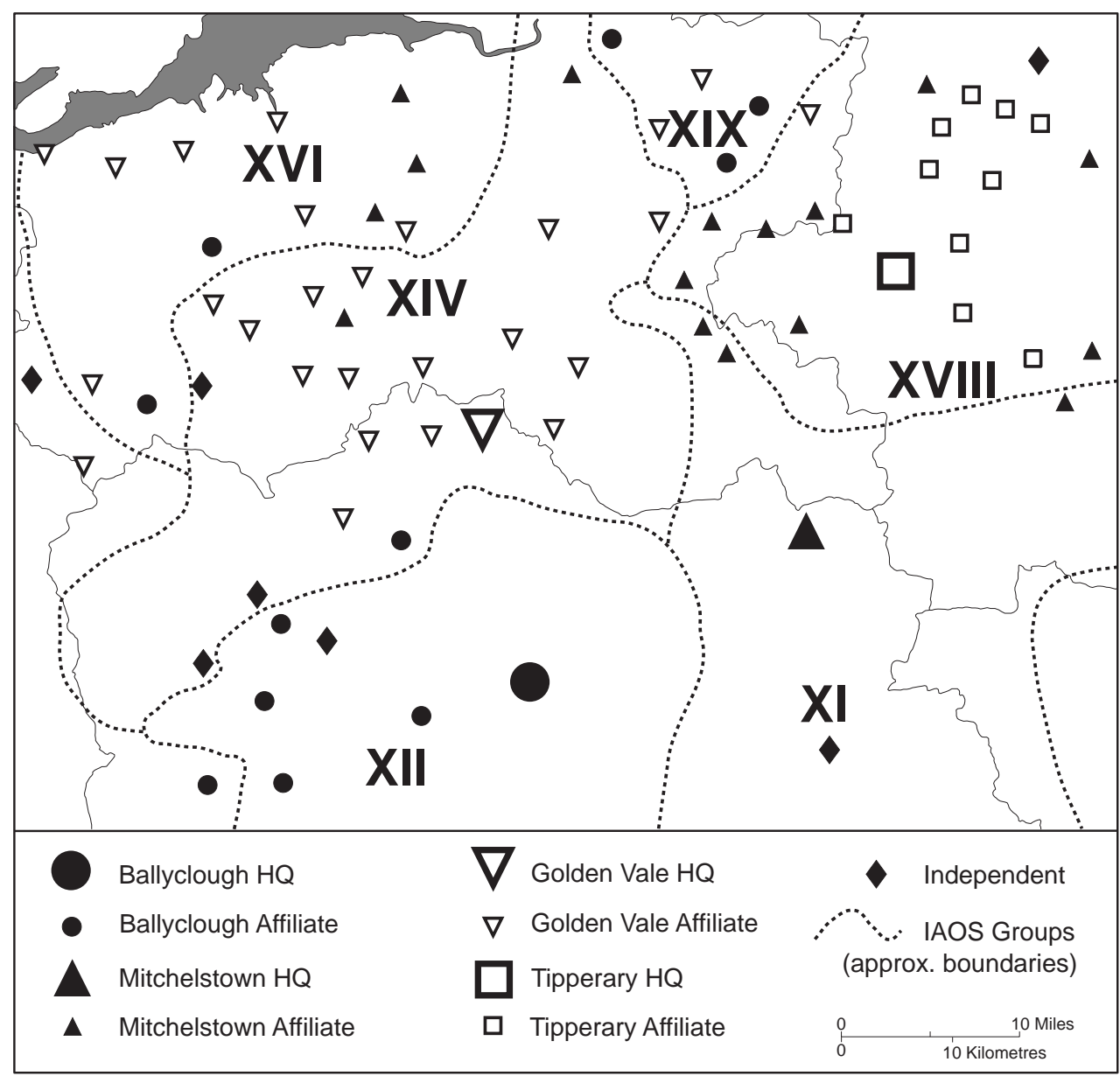

Figure 3: The pattern of post-1964 creamery amalgamation in the Mid-Munster dairying region.

Kerry-based grouping. At the same time, three units located at the western end of Group XIV chose to remain independent, another affiliated to the nearby Ballyclough Co-operative, and two others affiliated to Mitchelstown, despite the great distances involved.

Apart from the unit acquired from Group XIV, Ballyclough (Group XII) attracted two affiliates from Group XVI (north-west Limerick), three from faraway north-east Limerick (Group XIX) and another from near the Cork/Kerry border which had not been allocated to it by the IAOS. At the same time, the second largest unit within Group XII (the Kanturkbased North Cork Co-operative) chose to remain aloof from Ballyclough. Apart from the aforementioned two units which were recruited from Group XIV, Mitchelstown (Group XI) also succeeded in acquiring three units from Group XVI and no less than eight from Group XVIII (thereby greatly circumscribing the intended expansion of Tipperary Co-operative). However, Mitchelstown failed to entice the large Castlelyons Co-operative to the south; instead, the latter (shown as independent in Figure 3) eventually affiliated to Waterford Cooperative in a tit-for-tat exercise which saw Imokilly Co-operative (based further south in east Cork and allocated to Waterford by the IAOS) opting instead for Mitchelstown. 
As regards Group XVIII, most of the units which amalgamated with Tipperary Cooperative had been operated by the DDC (and were transferred to Tipperary by administrative fiat). The remainder of the units in the group either remained independent or affiliated to Mitchelstown or (in just one case) to Golden Vale. None of the five units in that portion of Group XIX included in Figure 3 affiliated to Nenagh Co-operative, as envisaged by the IAOS, opting instead for either Golden Vale or Ballyclough. Finally, not surprisingly, the misconceived Group XVI never got off the ground, with its constituent units all being absorbed in piecemeal fashion by Golden Vale, Ballyclough and Mitchelstown.

The overall outcome of this sequence of amalgamations was to produce a territorial mishmash, leading to a situation where milk tankers from the different groups regularly cut across the territories of the other groups on their way to their parent processing plants. The territorial fragmentation which attended the amalgamation process in the Mid-Munster region in the early 1970s was largely avoided elsewhere in the country, with new combined co-operatives such as Avonmore (formed in 1973 from the amalgamation of 21 smaller co-operatives located mainly in county Kilkenny and east Tipperary), Kerry (established in 1973 from a mixture of DDC creameries and small co-operatives) and North Connacht Farmers (established in 1972) forming coherent, spatially-contiguous units (Figure 4). However, the peculiar arc-shaped territory of the enlarged Waterford Co-operative, stretching from east Cork through Waterford, south Kilkenny, Wexford and south Wicklow (Figure 4) was a further testament to the unplanned and piecemeal manner in which the amalgamation process proceeded over much of the country.

\section{The recent amalgamation experience}

What could be considered the 'first wave' of co-operative amalgamations was largely completed by the mid-1970s, when the 192 creamery units covered by the IAOS 1966 proposals had been collapsed into less than 50 co-operatives - still greatly in excess of the nineteen envisaged in those proposals. Six dominant co-operatives had emerged from this amalgamation wave - Waterford, Mitchelstown, Ballyclough, Golden Vale (which in 1974 had acquired the DDC operations which accounted for the bulk of dairy processing in county Clare), Avonmore, and Kerry. Apart from this 'big six', a second tier of new consolidated cooperatives had emerged from the amalgamation process, while there was also a number of survivors from before the amalgamation era.

In 1979 the IAOS (now ICOS, the Irish Co-operative Organisation Society) issued a new set of reorganisation proposals which envisaged a reduction in the total number of cooperatives to just eleven regional groupings (ICOS, 1979). These proposals, in essence, involved the smaller remaining co-operatives joining up with the bigger entities which had emerged from the first amalgamation phase. The proposals also called for the geographical anomalies which had emerged from the latter phase to be "ironed out by agreement", a plea which (not unlike the main proposals themselves) largely fell on deaf ears. Nevertheless, further piecemeal acquisitions of smaller units saw the total number of co-operatives falling to 35 in 1990, when a second phase of amalgamations was ushered in involving the coalescence of co-operatives which had emerged from the first phase. There were two such amalgamations in that year- between Lough Egish and Killeshandra to form Lakeland Dairies (operating mainly in Cavan, Monaghan and north Leinster) and between Ballyclough and Mitchelstown to form Dairygold. 
A further significant development in 1990 was the takeover by Golden Vale of the former Westmeath and Bailieboro Co-operatives which had earlier been bought out by a privatelyowned agri-business organisation. This marked the first move by a Munster-based cooperative into the northern dairy belt, and was followed two years later by Waterford Cooperative which purchased the Express Foods Virginia Milk Products plant in county Cavan (along with Express Foods' Premier Dairies operation in Dublin). This was just one of a number of buy-outs of foreign-owned processing plants by the stronger co-operatives which emerged from the amalgamation process (Foley, 1993). These two moves, in turn, were in direct contravention of yet another plan, proposed by ICOS in 1987, for the consolidation of all remaining co-operatives into just three territorially-based units- one in the south, one in the north-east, and one in the north and west (ICOS, 1987). Such a radical move, the ICOS argued, was necessary if the Irish dairy industry was to remain competitive in international markets: in 1990, the largest Irish co-operative had a turnover only one third and one half, respectively, of those of its Dutch and Danish counterparts (The Irish Times, $20^{\text {th }}$ September 1991).

Figure 4 shows the territorial structure of the dairy processing industry in 1995, arising from the second phase of amalgamation and takeover in the industry. In addition to the continuing spatial fragmentation in Munster, a key feature of this structure is the large swathes of overlapping territories in east Connacht, north Leinster and south Ulster, and in the Inishowen district of Donegal. This is mainly attributable to the aforementioned acquisitions by Golden Vale and Waterford Co-operative respectively of the operations of the former Westmeath and Bailieboro Co-operative and Express Foods. Clearly, considerable room remained for territorial rationalisation in the industry, with the Golden Vale and Waterford acquisitions virtually ruling out any possibility of distinctive regional groupings emerging, as envisaged by ICOS in its 1987 proposals.

Nevertheless, one of the main building blocks in these proposals came to fruition in 1997 with the amalgamation of the adjoining Avonmore and Waterford groups to form Glanbia plc. Including previously-acquired international operations (see below), this is now one of the largest dairy processing enterprises in the world. The high level of internal opposition to which this merger gave rise, and the poor commercial performance of the combined group (at least in its initial years), were hardly conducive to further large-scale amalgamations in the industry. At the same time, further rationalisation seems inevitable in the increasingly competitive international market environment which obtains at the turn of the twenty-first century. This was clearly signalled in a further set of proposals for restructuring the industry published by ICOS in early 2000 (ICOS, 2000). Pointing to the very advanced level of rationalisation achieved by major competitors (in Denmark, the largest dairy group now handles 87 percent of the national milk supply; in the Netherlands and New Zealand, the two largest groups between them account for 85 percent and 94 percent, respectively), ICOS argued that a single national dairy business offered the maximum potential for optimising the efficiency of milk assembly and processing. Further movement in this direction is indicated by media reports in early 2000 that the Golden Vale group is considering a joint venture with another dairy group (presumably its neighbour Dairygold) in order to combat mounting losses at its processing plant at Charleville (The Irish Times, 20 ${ }^{\text {th }}$ May 2000). 


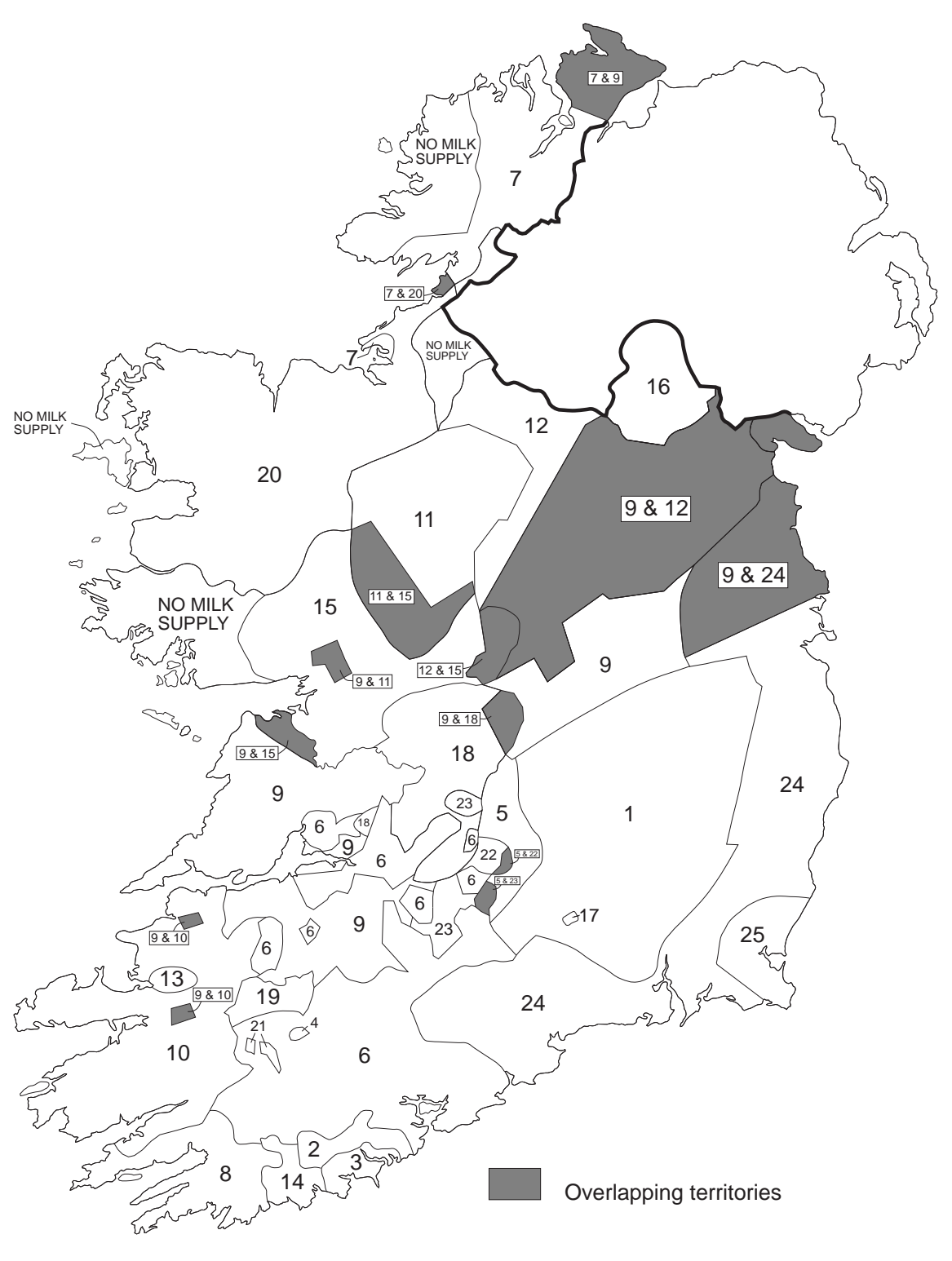

Figure 4: Dairy co-operative territories 1995.

Derived from Manufacturing Milk Supply Map of Ireland 1995, compiled by Joe Rea, Irish Farmers' Journal, $16^{\text {th }}$ September 1995.

Key to Regions -

$\begin{array}{llllll}1 & \text { Avonmore } & 10 & \text { Kerry } & 19 & \text { Newmarket } \\ 2 & \text { Bandon } & 11 & \text { Kiltoghert } & 20 & \text { North Connacht Farmers } \\ 3 & \text { Barryroe } & 12 & \text { Lakeland } & 21 & \text { North Cork } \\ 4 & \text { Boherbue } & 13 & \text { Lee Strand } & 22 & \text { Thurles } \\ 5 & \text { Centenary } & 14 & \text { Lisavaird } & 23 & \text { Tipperary } \\ 6 & \text { Dairygold } & 15 & \text { Midwest } & 24 & \text { Waterford } \\ 7 & \text { Donegal } & 16 & \text { Monaghan } & 25 & \text { Wexford } \\ 8 & \text { Drinagh } & 17 & \text { Mullinahone } & & \\ 9 & \text { Golden Vale } & 18 & \text { Nenagh } & & \end{array}$




\section{Internal rationalisation within co-operatives}

While the process of amalgamation between co-operatives may not have been particularly rational, amalgamation has generally been followed by considerable rationalisation within co-operatives. From a spatial point of view, the two most important forms of rationalisation were the concentration of milk processing and the closure of the branch creamery structure. As regards the first of these, prior to amalgamation, all individual co-operatives would have had their own milk processing operations (usually butter manufacture). Following amalgamation, processing was generally discontinued in the smaller locations and centralised in the major plants. This is well illustrated in Figure 5, which shows the impact of post-amalgamation rationalisation on the geographical distribution of milk processing in the then Waterford and Avonmore territories in south-east Ireland. Former processing locations have, in most cases, continued to provide store and retail functions, although some have either been sold off or closed down altogether.
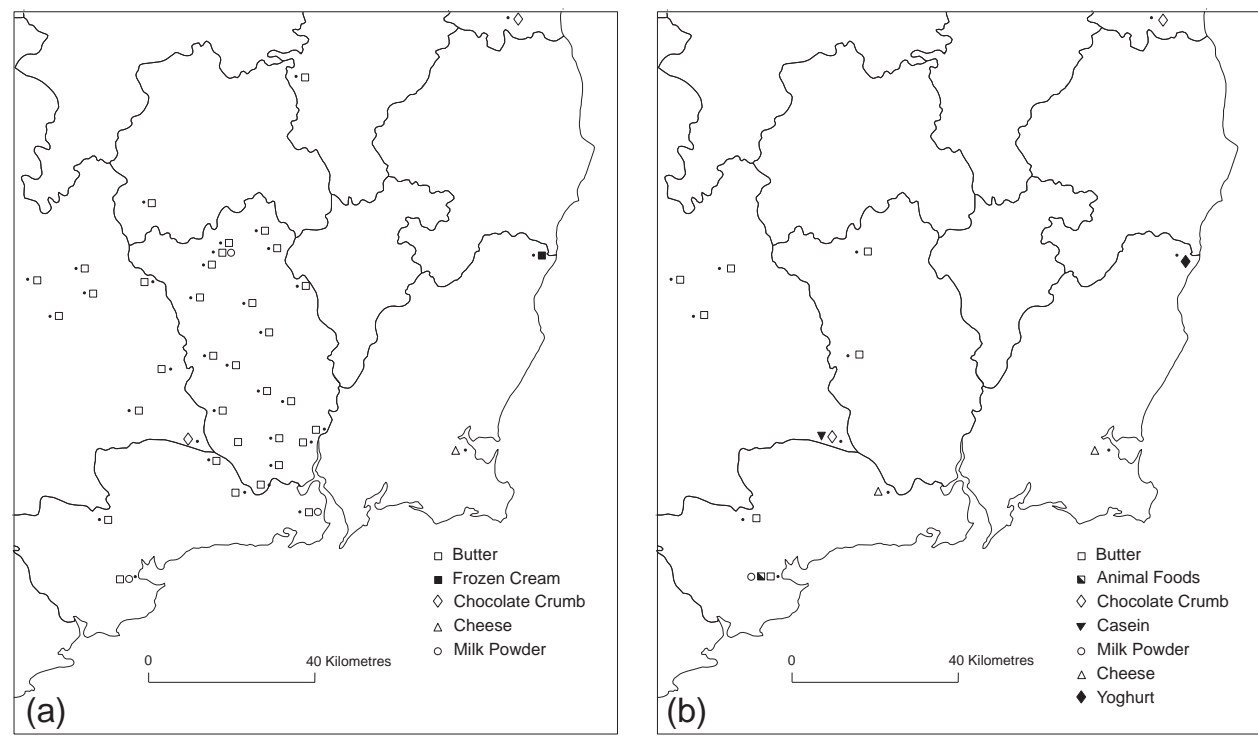

Figure 5: Locations of dairy processing plants in south-east Ireland:

(a) Beginning 1971; (b) End 1973.

(Sources: Leamy, 1974; Breathnach, 1992).

\section{The demise of the branch creamery}

As noted earlier, the spatial structure of the early creamery system in Ireland was based on a system of central processing plants and a network of auxiliary or branch creameries where milk was separated. However, the development of modern forms of transportation and the increasing tendency to use all the milk in dairy processing meant that the branch system was rendered redundant. Initially, the separating function was discontinued, but the branches continued to act as assembly points, to which milk was brought by farmers for transfer to trucks for onward delivery to central processing plants. However, growing levels of milk output per farm meant that economies of scale in long-distance deliveries of milk from individual farms were increasingly attainable. In Waterford, the bulk tank collection system 
was introduced in 1963 and by 1980 was being used by 95 percent of suppliers. As a result, the assembly function of the former branch creameries also largely disappeared, although it still survives in areas where dairy herds are too small to warrant direct collection.

Despite its centrality to the social life of the dairying regions (as noted earlier), the daily visit to the creamery was swept away over large areas in a space of less than a decade. While many regarded this development as detrimental socially, few were prepared to prioritise this over the economic benefits of rationalisation (Kennedy, 1976). For the larger and more progressive farmers who were the main beneficiaries of rationalisation, the daily trip to the creamery was increasingly seen as a waste of valuable time. For these, the information networks built around this trip were now being replaced by more formal information channels such as the mass media and technical advisors provided either by the State advisory service or the co-operatives themselves (Bohlen and Breathnach, 1970).

\section{Concentration of milk production}

Off-farm rationalisation in the Irish dairy industry over the last forty years has been accompanied by growing on-farm concentration of milk production among a declining number of increasingly large producers. This is linked to the inability of smaller producers to meet the increasing demands of the industry in terms of equipment, material inputs, skills and hygiene standards. Nationally, there were 110,000 farmers supplying creamery milk in 1966. Of these, 98 percent supplied less than 15,000 gallons $(680 \mathrm{Hl})$ each. By 1988, the number of suppliers had been reduced by over one half (to 50,000). Of these, only 54 percent supplied less than 15,000 gallons $(680 \mathrm{Hl})$, and between them, these accounted for just nineteen percent of total supplies. At the same time, the five percent of suppliers who each produced over 60,000 gallons $(2700 \mathrm{Hl})$ accounted jointly for 21 percent of all supplies.

This process of concentration is, of course, a general feature of recent agricultural change in advanced market economies and has, according to Wallace (1985: 499) -

"served progressively to polarise the farming community into a minority of highly capitalised, large-scale enterprises, which account for a growing proportion of total agricultural production, and a vulnerable majority of inadequately capitalised farms whose ability to provide their proprietors with a livelihood is being increasingly undermined."

Those farmers who have been squeezed out of dairying have generally been pushed into less intensive enterprises (particularly beef production) which give a lower return, thereby reducing even further what, in most of the cases in question, were already low farm incomes. While many of these farmers have been able to stay on in farming on a part-time basis by obtaining off-farm employment or social welfare assistance, ultimately the predominant outcome is, or will be, a complete exit from farming on the part of the families concerned. This is having a particularly destructive impact on those areas, such as west Cork, Clare and south Ulster, where dairying had been the mainstay of small-farming communities. An additional problem for these areas was the introduction by the European Union of the milk quota system in 1984, which made it impossible for dairy farmers to expand output except through acquiring the quotas of those leaving the industry. Small farmers generally have found it difficult to compete for these quotas against bigger dairy farmers, frequently located in other parts of the country. Because of the widespread community reverberations of largescale abandonment of dairying in small-farm areas which had been predominantly dependent 
on the industry, there is a strong case for special measures to assist at least the most capable dairy farmers in these areas (Breathnach and Kenny, 1997); however, it is likely that in most cases the process of decline is now irretrievable.

One of the traditional arguments in favour of agricultural co-operatives is that they provide the small producer in particular with a degree of protection and countervailing power in their transactions with input suppliers and with the downstream processing and marketing sectors (Hart, 1992). However, all the evidence is that most Irish dairy co-operatives have either encouraged, or acquiesced in, the elimination of the small producer from the industry. This may be attributed in part to the increasing control of co-operatives exercised by professional managers whose primary concerns are growth and profitability rather than the welfare of their weaker members (Tovey, 1982; Curtin and Varley, 1992). These concerns are also foremost among the private shareholders who have been securing a growing stake in the industry in recent years (see below). However, undoubtedly of even greater importance is the power of market forces in a situation of growing competitiveness in European and world markets. In this situation, the very survival of co-operatives is seen as being dependent on increased efficiency which in turn is seen as requiring the elimination of those suppliers who are regarded as being incapable of reaching the desired levels of efficiency.

\section{Internationalisation}

Two major, and interrelated, developments have dominated the restructuring of the main Irish dairy processors in the 1990s. These refer to movement into overseas production activities and increasing reliance on the private stock market as a means of financing investment. By 1990, corporate concentration in the dairy industry had reached an advanced stage, with the top five co-operatives (Kerry, Waterford, Avonmore, Dairygold and Golden Vale) accounting for three quarters of total turnover. At this stage, the amalgamation process had proceeded sufficiently to limit greatly the scope for further external expansion via the takover of smaller co-operatives, while the introduction of the milk quota system in 1984 meant that the expanded milk supplies required for internal expansion would no longer be forthcoming within Ireland.

While some of the larger co-operatives have pursued further expansion in Ireland via diversification (particularly into meat processing), overseas expansion (mainly via acquisition) has been of far greater signficance. The dominant figure in overseas expansion by Irish dairy groups has been the Kerry Group, which first moved into both the UK and the USA in 1987, prior to acquiring further operations in Germany, Italy, Poland, Australia, Canada and Mexico in the following seven years. The main focus of these acquisitions has been the food ingredients sector, which now accounts for over half of group turnover, making Kerry a major world player in the industry. When Kerry paid £IR250M for the US-based DCA food ingredients firm in 1994, it was the third biggest corporate acquisition ever made by an Irish firm. In 1998, Kerry paid a further £STG335M for Dalgety Food Ingredients. As a result of these and other overseas acqusitions, in 1998 only 26 percent of Kerry's turnover originated in Ireland compared with 44 percent in Europe, 26 percent in North America and three percent in the Asia-Pacific region. Less than ten percent of total turnover derived from dairy products.

Prior to their amalgamation in 1997, both Avonmore and Waterford had engaged in substantial overseas investments, mainly in the UK and the USA. By contrast, the overseas 
acquisitions of Dairygold and Golden Vale have been quite modest. It is also worth mentioning that the Irish Dairy Board (formerly known as An Bord Bainne), which now comprises a co-operative whose members are the Irish dairy co-operatives, and which has mainly acted as an overseas marketing agency for the Irish dairy industry, has in recent years acquired a number of manufacturing plants in the UK, Belgium and the USA. The Board's overseas operations now account for some 45 percent of total turnover.

\section{Privatisation}

The acquisition of major overseas activities by the leading Irish dairy groups has been associated with profound changes in their nature as business entities, relating in particular to their gradual transformation from co-operatives to private enterprises. Four of the big five, led by Kerry in 1986, have created structures whereby the original co-operative was set up as a holding company, with all operations being transferred to a subsidiary company, part of whose shares have been sold on the open market. While, initially, the original co-operative retained the great majority of the shares in the operating company, over time the tendency has been to dilute this shareholding, and in 1997, Kerry Co-operative decided to allow its shareholding in Kerry Group to fall to just 39 percent, with provision for a further dilution down to 20 percent ultimately. Dairygold is now the only one of the big five Irish dairy businesses which remains entirely farmer-owned.

The common justification for this development is that it has provided the groups in question with a mechanism to obtain the capital required for expansion, in a situation where the original farmer shareholders were either unable or unwilling to put up the required capital investment. However, the bulk of the capital employed in expansion has come from the groups' own cash flow and from borrowings, and it is debatable whether the resort to private shareholding was really necessary. In both the USA and Australia, dairy co-operatives have found innovative ways of raising capital without resort to privatisation (Pritchard, 1996).

It is clear that the momentum behind privatisation has emanated from the dairy groups' professional management, at least partly because of their belief that a conventional corporate structure is necessary in an increasingly competitive international environment. Among the key consequences are that share price and profitability will replace the milk price as the key performance indicator among the big dairy groups (involving a profound change in the relationship between the groups and their milk suppliers), and that the dairy processing industry - perhaps the only major modernised Irish industry still predominantly under Irish control — now becomes susceptible to external takeover.

\section{Conclusion}

The modern Irish dairy industry clearly has changed very profoundly in the one hundred years or so since the first creameries were established in the late-nineteenth century. The combined forces of modernisation, commercialisation and technological change have transformed a multiplicity of tiny, localised and strongly community-based operations into an industry dominated by a handful of corporate agribusinesses whose orientation is now strongly transnational. A key theme which has run through the industry's evolutionary trajectory has been the ongoing failure of dairy farmers to exert ownership and control over the co-operatives of which they were members. Instead, the great majority of farmers were content to confine their dealings with their co-operatives to day-to-day commercial 
transactions. As Bolger (1983) has remarked, to dairy farmers the 'co-op' was a building, not an organisation of which they were part. This ceded to management a degree of control which assumed growing significance as the process of corporate concentration in the industry proceeded. Among the consequences of this development for the dairy farmers themselves has been that only a minority have survived in the industry, and even these have seen their status essentially reduced to that of contract farmers, whose relationship with the agribusiness which they supply is purely commercial.

\section{Note}

1 The data for this section of the paper were mainly obtained from the IAOS and individual co-operatives.

\section{References}

BOHLEN, J.M. and BREATHNACH, T. (1970) Irish farmers' use of information sources, Irish Journal of Agricultural Economics and Rural Sociology, 2(1), 1-28.

BOLGER, P. (1977) The Irish co-operative movement: its history and development. Dublin: Institute of Public Administration.

BOLGER, P. (1983) The dreadful years, In: Keating, C. (ed.) Plunkett and co-operatives. Cork: Bank of Ireland Centre for Co-operative Studies, University College Cork, 111-118.

BOWLER, I.R. (ed.) (1992a) The geography of agriculture in developed market economies. Harlow: Longman.

BOWLER, I.R. (1992b) The industrialisation of agriculture, In: Bowler, I.R. (ed.) The geography of agriculture in developed market economies. Harlow: Longman, 7-31.

BOWLER, I.R. and ILBERY, B.W. (1987) Redefining agricultural geography, Area, 19(4), 327-332.

BREATHNACH, P. (1992) The development of the dairy industry in county Waterford, In: Nolan, W. and Power, T.P. (eds) Waterford: history and society. Dublin: Geography Publications, 707-732.

BREATHNACH, P. and KENNY, M. (1997) The impact of Irish dairy industry rationalisation on the sustainability of small farming communities, In: Byron, R., Walsh, J. and Breathnach, P. (eds) Sustainable development on the North Atlantic margin. Aldershot: Ashgate, 323-338.

CURTIN, C. and VARLEY, T. (1992) Cooperation in rural Ireland: an approach in terminal crisis?, In: Ó Cinnéide, M. and Cuddy, M. (eds) Perspectives on rural development in advanced economies. Galway: Social Sciences Research Centre, University College, Galway, 111-122.

DALY, P. (1991) The early development of the creamery system in Ireland 1880-1914. Unpublished MA thesis. Maynooth: Department of Geography, National University of Ireland, Maynooth.

FOLEY, J. (1993) The Irish dairy industry: a historical perspective, Journal of the Society of Dairy Technology, 46(4), 123-138.

FRAWLEY, J. (1973) Social aspects of creamery rationalisation, Irish Agricultural and Creamery Review, December, 13-25.

HART, P. (1992) Marketing agricultural produce, In: Bowler, I.R. (ed.) The geography of agriculture in developed market economies. Harlow: Longman, 162-206.

HAUGHTON, J.P. and GILLMOR, D.A. (1979) The geography of Ireland. Dublin: Department of Foreign Affairs.

HEALEY, M.J. and ILBERY, B.W. (eds) (1985a) The industrialisation of the countryside. Norwich: Geo Books.

HEALEY, M.J. and ILBERY, B.W. (1985b) The industrialisation of the countryside: an overview, In: Healey, M.J. and Ilbery, B.W. (eds) The industrialisation of the countryside. Norwich: Geo Books, $1-26$.

IAOS (Irish Agricultural Organisation Society) (1966) Proposals for re-organisation in the dairy industry. Dublin: IAOS.

ICOS (Irish Co-operative Organisation Society) (1979) Framework for co-operative development. Dublin. 
ICOS (1987) Strategy for the Irish dairy industry. Dublin.

ICOS (2000) A strategic review of the Irish dairy sector. Dublin.

KEATING, C. (ed.) (1983) Plunkett and co-operatives. Cork: Bank of Ireland Centre for Co-operative Studies, University College Cork.

KENNEDY, K.A., GIBLIN, T. and McHUGH, D. (1988) The economic development of Ireland in the twentieth century. London: Routledge.

KENNEDY, L. (1976) Social and economic impacts of co-operative amalgamation: a case study, Irish Journal of Agricultural Economics and Rural Sociology, 6(2), 103-114.

KNAPP, J.K. (1964) An appraisement of agricultural co-operation in Ireland. Dublin: The Stationery Office.

LEAMY, J.F. (1974) The spatial redistribution and the structural reorganisation of the Irish cooperative creameries. Unpublished BA thesis. Dublin: Department of Geography, University College, Dublin.

LEE, J.J. (1989) Ireland 1912-1985: politics and society. Cambridge: Cambridge University Press.

MURTAGH, M. (1986) Proud heritage: The story of Imokilly Co-op. Dublin: Ben Bulben Press.

O'DWYER, T. (1968a) Determination of the optimum number, location and size of dairy manufacturing plants, Irish Journal of Agricultural Economics and Rural Sociology, 1(3), 267-281.

O'DWYER, T. (1968b) Economies of size in skim-milk powder production, Irish Journal of Agricultural Economics and Rural Sociology, 1(3), 253-265.

O'LEARY, C. (1983) Agricultural co-operatives in Ireland after Knapp, In: Keating, C. (ed.) Plunkett and co-operatives. Cork: Bank of Ireland Centre for Co-operative Studies, University College Cork, 119-156.

PRITCHARD, W. (1996) Shifts in food regimes, regulation, and producer cooperatives: insights from the Australian and US dairy industries, Environment and Planning A, 28, 857-875.

TOVEY, H. (1982) Milking the farmer? Modernisation and marginalisation in Irish dairy farming, In: Kelly, M., O'Dowd, L. and Wickham, J. (eds) Power, conflict and inequality. Dublin: Turoe Press, 68-89.

WALLACE, I. (1984) Towards a geography of agribusiness. Unpublished paper quoted in Healey, M.J. and Ilbery, B.W. (eds) (1985b) The industrialisation of the countryside: an overview. Norwich: Geo Books, 2.

WALLACE, I. (1985) Towards a geography of agribusiness, Progress in Human Geography, 9(4), 491514.

WHATMORE, S. (1993) From farming to agribusiness: the global agro-food system, In: Johnston, R.J., Taylor, P.J. and Watts, M.J. (eds) Geographies of global change. Oxford: Blackwell Publishers, 38-49. 